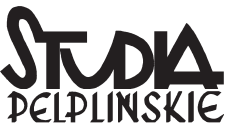

ISSN 0239-4456

eISSN 2391-8713

53(2019), s. $389-410$

KS. MAREK PARCHEM

Uniwersytet Kardynała Stefana Wyszyńskiego w Warszawie

mking@op.pl

ORCID: 0000-0001-7233-4702

\section{WYDARZENIA CZASÓW OSTATECZNYCH W HYMNICZNYCH PROROCTWACH ESCHATOLOGICZNYCH KSIĘGI DANIELA (Dn 12,1-3) I TESTAMENTU MOJŻESZA (TestMojż 10,1-10)}

DOI: http://dx.doi.org/10.12775/SPLP.2019.023

\section{Streszczenie}

W żydowskich pismach apokaliptycznych z okresu Drugiej Świątyni (III w. przed Chr. - początek II w. po Chr.) - a później także w apokalipsach chrześcijańskich - wydarzenia czasów eschatologicznych są przedstawiane jako ciąg kolejno następujących po sobie zdarzeń. Ostateczne wybawienie ludzi sprawiedliwych i wiernych Bogu oraz ustanowienie doskonałej i wiecznej rzeczywistości (tj. królestwa Bożego) będzie poprzedzone okresem ucisku i uaktywnieniem się sił zła, które zostaną pokonane i unicestwione dzięki zwycięskiej interwencji Boga. Treścią niniejszego artykułu jest analiza egzegetyczna dwóch hymnicznych proroctw eschatologicznych, które znajdują się w biblijnej Księdze Daniela (12,1-3) oraz w apokryficznym Testamencie Mojżesza $(10,1-10)$. Obydwa hymny pochodzą z połowy II wieku przed Chr., a więc z czasów kryzysu wywołanego prześladowaniami Żydów wszczętymi przez Antiocha Epifanesa. Obydwa powstały w tym samym środowisku, mianowicie w kręgach mądrościowych o proweniencji kapłańskiej, które skupiało się przede wszystkim na zachowaniu wierności Bogu, czystości i wspólnoty ze światem niebiańskim.

Słowa kluczowe: Księga Daniela; Testament Mojżesza; apokaliptyka; eschatologia; wydarzenia czasów ostatecznych; ucisk eschatologiczny; zmartwychwstanie; wywyższenie wiernych Bogu; wieczne zbawienie 
The Events of the Last Days in the Hymnic Eschatological Prophecies of the Book of Daniel (Dan 12:1-3) and in the Testament of Moses (TestMos 10:1-10)

\section{Summary}

In the Jewish apocalyptic writings of the Second Temple Period (from $3^{\text {rd }}$ century $\mathrm{BC}$ till $2^{\text {nd }}$ century AD) - and in the latter Christian apocalypses - events of the eschatological times are presented as a sequence of the consecutive events. The ultimate salvation of the righteous and the faithful to God and the establishment of the perfect and everlasting reality (i.e. the kingdom of God) will be preceded by a period of great oppression and the activity of evil powers that would finally be defeated and annihilated by the victorious Divine intervention. This article contains the exegetical analysis of two hymnic eschatological prophecies that are found in the biblical Book of Daniel (12:1-3) and in the apocryphal Testament of Moses (10:1-10). Both hymns date back to the mid-second century BC, that is from the time of crisis which was caused by Antiochus IV Epiphanes' persecutions of Jews. Both writings were composed in the same social milieu, namely, in the sapiential circles of the priestly origins that focused mostly on being faithful to God, on preserving the purity, and on remaining united with the community of the spiritual world of heaven.

Keywords: Book of Daniel; Testament of Moses; apocalyptic; eschatology; events of the Last Days; eschatological oppression; resurrection; exaltation of the righteous and faithful; eternal salvation

W pismach o charakterze apokaliptycznym wydarzenia czasów ostatecznych są przedstawiane jako ciąg kolejno następujących po sobie zdarzeń. Wybawienie ludzi sprawiedliwych i wiernych Bogu oraz ustanowienie doskonałej i wiecznej rzeczywistości będzie poprzedzone okresem ucisku i uaktywnieniem się sił zła, które zostaną pokonane i unicestwione dzięki interwencji Boga, zakończonej Jego ostatecznym i całkowitym zwycięstwem. Innymi słowy, wieczne zbawienie i odnowienie całego świata zostanie zrealizowane przez Boga po okresie niespotykanych w dotychczasowej historii niepokojów społecznych i zachwiania porządku o zasięgu kosmicznym ${ }^{1}$. Przedstawione w ten sposób wydarzenia czasów osta-

Omówienie wydarzeń czasów ostatecznych w „porządku chronologicznym”, zob. P. Volz, Die Eschatologie der jüdischen Gemeinde im neutestamentlichen Zeitalter, J.C.B. Mohr (Paul Siebeck), Tübingen 1934 (reprint: Georg Olms Verlagsbuchhandlung, Hildesheim 1966), s. 135-419; E. Schürer, The History of the Jewish People in the Age of Jesus Christ (175 B.C. - A.D. 135). A New English Version Revised and Edited by G. Vermes, F. Millar, M. Black, T \& T Clark LTD, 
tecznych w żydowskich apokalipsach z okresu Drugiej Świątyni (III w. przed Chr. - II w. po Chr.) zostały później rozwinięte również w tradycji chrześcijańskiej.

Wydarzenia czasów ostatecznych - ujęte w pewnego rodzaju schemat następujących po sobie zdarzeń - zostały w sposób niezwykle skondensowany przedstawione w dwóch hymnicznych proroctwach eschatologicznych, które znajdują się w biblijnej Księdze Daniela (Dn 12,1-3) oraz w apokryficznym Testamencie Mojżesza (TestMojż 10,1-10). Obydwa hymny pochodzą mniej więcej z tego samego czasu, gdyż ich powstanie datuje się na połowę II wieku przed Chr., przy czym hymn z Księgi Daniela jest najprawdopodobniej nieco wcześniejszy. Jest to czas kryzysu wywołanego prześladowaniami Żydów wszczętymi przez Antiocha Epifanesa, króla z dynastii Seleucydów, w rezultacie których dokonano zniszczenia kultu i zbezczeszczenia Świątyni, czego następstwem był wybuch powstania machabejskiego. Obydwa hymny, a szerzej apokaliptyczne wizje w Dn 7-12 oraz Testament Mojżesza - powstały w tym samym środowisku, mianowicie w kręgach mądrościowych o proweniencji kapłańskiej, które skupiało się przede wszystkim na zachowaniu wierności Bogu, czystości i wspólnoty ze światem niebiańskim. Byli oni zwolennikami aktywnego sprzeciwu wobec prześladowań, jednak nie przez zbrojny opór (jak to jest np. w 1-2 Mch; Apokalipsie zwierząt, 1 Hen 85-90; Regule wojny z Qumran, $1 \mathrm{QM}$ ), lecz przez przyjmowanie cierpienia i śmierci ze względu na ich wartość oczyszczającą, bo w ten sposób można uzyskać uczestnictwo w zmartwychwstaniu i przyszłym zbawieniu (zob. Dn 11,32-35; 12,2-3; TestMojż 9,1-7)².

Edinburgh 1995, t. 2, s. 514-554; D.S. Russell, The Method and Message of Jewish Apocalyptic 200 BC - AD 100 (The Old Testament Library), The Westminster Press, Philadelphia 1964, s. 271-284; M. Parchem, ,, Co stanie się przy końcu dni” (Dn 2,28): wydarzenia czasów eschatologicznych ws świetle żydowskich pism apokaliptycznych okresu międzytestamentalnego, w: Czas Apokalipsy. Wizje dni ostatecznych w kulturze europejskiej od starożytności do wieku XVII, red. K. Zalewska-Lorkiewicz, Wydawnictwo Neriton, Warszawa 2013, s. 26-35.

2 Zob. G. Zerbe, Pacifism and Passive Resistance in Apocalyptic Writings: A Critical Evaluation, w: The Pseudepigrapha and Early Biblical Interpretation (Journal for the Study of the Pseudepigrapha. Supplement Series, 14; Studies in Scripture in Early Judaism and Christianity, 2), red. J.H. Charlesworth, C.A. Evans, JSOT Press, Sheffield 1993, s. 93-94; J.J. Collins, The Apocalyptic Imagination: An Introduction to Jewish Apocalyptic Literature (The Biblical Resource Series), William B. Eerdmans Publishing Company, Grand Rapids - Cambridge 1998, s. 111; szerzej na ten temat, zob. J.J. Collins, The Apocalyptic Vision of the Book of Daniel (Harvard Semitic Monographs, 16), Scholars Press, Missoula 1977, s. 191-218; M. Parchem, Ksiegga Daniela. Wstęp, przektad z oryginału, komentarz (Nowy Komentarz Biblijny. Stary Testament, 26), Edycja św. Pawła, Częstochowa 2008, s. 54-62. 


\section{HYMNICZNE PROROCTWO ESCHATOLOGICZNE W KSIEDZE DANIELA (Dn 12,1-3)}

Eschatologiczne proroctwo ujęte w formę hymnu (Dn 12,1-3), przedstawiające ostateczne wypełnienie historii, które dokona się poprzez zwycięstwo Boga nad siłami zła, zmartwychwstanie oraz nagrodę życia wiecznego dla sprawiedliwych i potępienie dla bezbożnych, stanowi punkt kulminacyjny apokaliptycznej wizji w Dn 10-12.

Treść proroctwa w Dn 12,1-3 przedstawia się następująco:

1 I w tym czasie powstanie Michat, wielki ksiązę,

który stoi nad synami twojego narodu.

I będzie czas ucisku

jakiego nie byto, od (poczatku) istnienia narodu, aż do tego czasu.

I w tym czasie zostanie ocalony twój naród,

każdy, który znajdzie się zapisany w księdze.

2 I wielu spośród tych, którzy śpia w prochu ziemi, - obudzi się-

niektórzy do życia wiecznego, a niektórzy do hańby, do odrazy wiecznej.

3 I mędrcy będa świecić jak blask firmamentu, a ci, którzy uczynili sprawiedliwymi wielu, jak gwiazdy, na wieki i zawsze.

Rozpoczęcie ciągu zdarzeń czasów ostatecznych wyrażają początkowe słowa „i w tym czasie” (ובעת ההיא), które nawiązują do treści wizji, w której anioł interpretator przedstawił Danielowi historię od czasów perskich aż do śmierci Antiocha Epifanesa (11,1-45). W sposób bezpośredni słowa te odnoszą się do czasu ataku Antiocha Epifanesa na ziemię Izraela oraz jego śmierci, co według 11,40 stanie się „W czasie końca” (בעת קץ). Śmierć pogańskiego króla, który wszczął prześladowania i wystąpił przeciwko samemu Bogu (zob. Dn 7,25-26; 8,25; 11,36), jest inauguracją czasów ostatecznych. Innymi słowy, dla autora Dn 10-12 panowanie Antiocha Epifanesa, zakończone jego haniebną śmiercią, staje się początkiem końca, a więc przełomem, po którym nastąpi wybawienie tych, którzy okazali się wierni Bogu.

Nadejście przełomowego i jednocześnie rozstrzygającego momentu w historii rozpoczyna się od pojawienia się „Michała, wielkiego księcia”, który jest ukazany w Dn 10-12 jako opiekun i obrońca narodu Izraela. Michał (מיכאל, ,Kto 
jest jak Bóg?") występujący w roli niebiańskiego wojownika walczącego w obronie / dla Izraela jest tym, który realizuje postanowienia powzięte przez Boga (zob. Dn 10,13.21; zob. też 1 Hen 10,11-16; 1QM 17,6-8; Ap 12,7-9)³. Krótko mówiąc, Michał działa w imieniu Boga i z Jego polecenia, a to oznacza, że jedynym i prawdziwym inspiratorem wydarzeń eschatologicznych jest sam Bóg. W odnie-

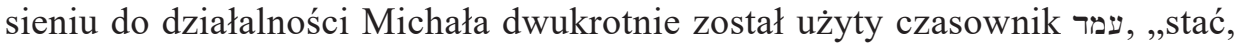
powstać”. W pierwszym przypadku: ,powstanie (יעמר) Michał”, chodzi o jego pojawienie się w zastępstwie Boga jako głównego uczestnika wydarzeń czasów ostatecznych. W drugim przypadku: „(ten), który stoi nad (העמד על) synami twojego narodu”, podkreśla się jego rolę jako „przywódcy”, ale również jako „obrońcy, opiekuna”. Jak słusznie sugeruje G.W.E. Nickelsburg, rola Michała nie ogranicza się jedynie do wymiaru militarnego, co zostaje uwypuklone zwłaszcza w Dn 10, ale obejmuje również aspekt jurydyczny, a więc jest on obrońcą i wykonawcą wyroku wydanego przez Boga, co podkreśla Dn 12,1. Eschatologiczna wojna, której przewodzi Michał, ma równocześnie charakter sądu, a zwycięstwo $\mathrm{w}$ walce staje się jednoczesnym ukaraniem tych, którzy sprzeciwiają się Bogu ${ }^{4}$.

Moment, w którym dokona się decydujący przełom w historii jest określony jako „czas ucisku (עת צרה), jakiego nie było, od (początku) istnienia narodu, aż do tego czasu". Chociaż w tekście nie ma mowy, na czym dokładnie będzie polegał „ucisk”, to jednak z kontekstu całej wizji (Dn 10-12) można wnioskować, że chodzi o prześladowania i śmierć wiernych Bogu (zob. Dn 11,33-35). Warto zauważyć, że wspomniany przez autora hymnu w Dn 12,1 „czas ucisku” jest jednocześnie postrzegany jako okres inauguracji ostatecznego zwycięstwa Boga nad złem, gdyż „w tym czasie zostanie ocalony (ימלט) twój naród”. Pojawiający się po raz drugi zwrot „,W tym czasie” (ובעת ההיא) odnosi się bezpośrednio do ocalenia z niebezpieczeństwa wynikającego z działań Antiocha Epifanesa, ale to wybawienie odnosi się również do czasów ostatecznych i obejmuje swoim zakresem uratowanie z wszelkiego rodzaju niebezpieczeństw i zagrożeń. Warto jeszcze dodać, że czasownik מלט, „ocalić; uratować; wybawić; uchronić od niebezpieczeństwa", użyty tutaj w formie nifal wyraża myśl, iż ocalenia dokona sam Bóg. Na uwagę zasługuje identyczny motyw „czasu ucisku” pojawiający się w Regule

Zob. M. Hengel, Judaism and Hellenism: Studies in their Encounter in Palestine during the Early Hellenistic Period, tt. J. Bowden, SCM Press Ltd, London 1996, t. 1, s. 188; szerzej na ten temat, zob. M. Parchem, Ostateczne zwycięstwo Boga w walce między dobrem a złem w świetle pism z Qumran (Rozprawy i Studia Biblijne, 30), Oficyna Wydawnicza „Vocatio”, Warszawa 2008, s. 158-164; tenże, Rola Michała w przekazach o „,buncie w niebiosach” oraz „,upadku aniołów”, w: Michat Archaniol, Zagadnienia teologiczne, red. H. Oleschko, S. Łącki, Wydawnictwo Michalineum, Marki 2012, t. 1, s. 123-164.

4 Zob. G.W.E. Nickelsburg, Resurrection, Immortality, and Eternal Life in Intertestamental Judaism (Harvard Theological Studies, 26), Harvard University Press, Cambridge - Oxford University Press, London 1972, s. 14; J.J. Collins, Daniel: A Commentary on the Book of Daniel (Hermeneia), Fortress Press, Minneapolis 1993, s. 390; M. Parchem, Ksiegga Daniela, s. 672-673. 
wojny (1QM), dokumencie qumrańskim często inspirującym się Księgą Daniela. Czas ucisku jest tutaj postrzegany jako okres bezpośrednio poprzedzający ostateczną wojnę synów światłości z synami ciemności: „I będzie to czas ucisku dla całego ludu odkupionego przez Boga. A wśród wszystkich ich ucisków nie było takiego, jak ten, od początku, aż do dopełnienia się odkupienia wiecznego" (1QM 1,11-12). W 1QM - podobnie jak w Dn 12,1 - czas ucisku ma aspekt negatywny (tj. uaktywnienie sił zła) oraz aspekt pozytywny (tj. ocalenie synów światłości = ludu Bożego). Ostatecznym rezultatem oczyszczenia w okresie próby stanie się wybawienie wiernych Bogu, które będzie równoznaczne z wiecznym panowaniem ludu Bożego i równoczesnym zniszczeniem sił zła, którym przewodził Belial: „będzie to czas wybawienia (עת ישועה) dla ludu Bożego, i okres panowania dla wszystkich ludzi Jego obozu, ale wiecznego zniszczenia dla całego obozu Beliala" (1QM 1,5). Zarówno w Księdze Daniela, jak i w 1QM, czas ucisku, stanowiący swoistego rodzaju preludium ciągu zdarzeń czasów eschatologicznych, jest postrzegany jako okres próby dla wiernych Bogu, który umożliwia oczyszczenie, a ostatecznie uczestnictwo w zbawieniu.

Kolejnym wydarzeniem czasów ostatecznych jest zmartwychwstanie (Dn 12,2), które zostało przedstawione w sposób metaforyczny jako obudzenie się ze snu: „wielu spośród tych, którzy śpią (מישני) w prochu ziemi, obudzi się (יקיצו)". Metafora ukazująca śmierć jako sen jest znana w literaturze starożytnego Bliskiego $W_{s c h o d u}^{5}$ oraz w tradycji biblijnej (zob. Hi 3,13; 14,12; Ps 13,4; Jr 51,39.57), przy czym należy zauważyć, że służy ona podkreśleniu prawdy o niemożliwości powrotu do życia ${ }^{6}$. W Dn 12,2 jest natomiast w sposób wyraźny, jednoznaczny i bezpośredni mowa o wskrzeszeniu zmarłych do życia ${ }^{7}$. Używając wyrażenia „W prochu ziemi”, które najprawdopodobniej oznacza tutaj Szeol, a więc miejsce przebywania zmarłych (por. Hi 17,16), autor Dn 12,2 wykorzystuje biblijną terminologię łączącą motyw prochu i śmierci, między innymi występującą w Ps 30,10,

5 Określenie umarłych jako tych, którzy śpią pojawia się m. in. w literaturze egipskiej i akadyjskiej, zob. K.-J. Illman, H. Ringgren, H.-J. Fabry, mût, et al., w: Theological Dictionary of the Old Testament, red. G.J. Botterweck, H. Ringgren, H.-J. Fabry, tt. D.W. Stott, William B. Eerdmans Publishing Company, Grand Rapids - Cambridge 1997, t. 8, s. 187-189.

6 Np. według Hi 14,12 śmierć jest stanem trwałym i człowiek nie ma żadnej możliwości powrotu do życia: „gdy człowiek położy się spać, to nie wstanie aż przestaną istnieć niebiosa, nie obudzą się (לאי יקיצו) i nie ockną się ze swojego snu (משנתם)"; w Jr 51,39.57 niemożność obudzenia się ze snu (tj. śmierci) jest karą wymierzoną przez Boga za zniszczenie Jerozolimy: ,i zasną snem wiecznym (וישנו שנת עולם), i nie obudzą się (ולא יקיצו)"; w 2 Krl 4,31 wyrażenie „nie obudził się" pełni rolę stwierdzenia zgonu; więcej na ten temat, zob. T.H. McAlpine, Sleep, Divine and Human in the Old Testament (Journal for the Study of the Old Testament. Supplement Series, 38), JSOT Press, Sheffield 1987, s. 135-149.

7 Zob. dyskusję na ten temat w: M. Parchem, Motyw zmartwychwstania w Księdze Daniela (Dn 12,2), w: Scripturae Lumen, Biblia i jej oddziaływanie: Zmartwychwstat prawdziwie, red. A. Paciorek, i in., Wydawnictwo Biblos, Tarnów 2010, t. 2, s. 65-77. 
gdzie ,proch” jest synonimem zmarłego, czy też w stwierdzeniu, że zmarli to „mieszkańcy prochu” (Iz 26,19), zaś umieranie to „położenie się w prochu” (Hi 7,21; 20,11; 21,26) oraz ,zstąpienie do prochu” (Hi 17,16; Ps 22,30). Należy zwrócić uwagę, że autor Dn 12,2 nie podejmuje motywu zmartwychwstania w sensie powszechnym, ponieważ koncentruje się na losie narodu Izraela (por. „,twój naród” w w. 1), a ściślej - przedstawia los wiernych Bogu oraz ich przeciwników w konflikcie, który miał miejsce w czasach panowania Antiocha Epifanesa. Na takie rozumienie wskazuje przyimek מן, מישני ,spośró, ,són z", w zwrocied tych, którzy śpią", który przybiera tu sens cząstkowy (tj. genetivus partitivus) ${ }^{8}$. Innymi słowy, nie chodzi o ,wszystkich”, którzy umarli, ale jedynie o ,wielu” spośród umarłych, a więc liczbę śpiących w prochu ziemi bliżej nieokreśloną.

Jak słusznie zauważa G.W.E. Nickelsburg, zmartwychwstanie w Dn 12,2 jest równocześnie sądem ${ }^{9}$. Podczas gdy w w. 1 wspomina się o ocaleniu sprawiedliwych spośród narodu Izraela (,każdy, który znajdzie się zapisany w księdze”), to w w. 2 pojawia się myśl, że Bóg osądzi również zmarłych, którzy zmartwychwstaną po to, aby otrzymać odpłatę, mianowicie wywyższenie bądź potępienie. Autor Dn 12,2 wyraźnie wyodrębnia dwie grupy w opisie tych, którzy zmartwychwstaną, co wyraża konstrukcja אילה ..., ואלה, ,niektórzy ... a niektórzy”. Według tego podziału na dwie odrębne kategorie ludzi, niektórzy zmartwychwstaną „do życia wiecznego”, natomiast inni „do hańby, do odrazy wiecznej”.

Wyrażenie ,życie wieczne" (חיי עולם), które w takiej formie pojawia się w Biblii Hebrajskiej tylko w tym miejscu (por. Ps 133,3), jest postrzegane jako określenie nagrody. Otrzymają ją ci, którzy w czasie prześladowań wszczętych przez Antiocha Epifanesa pozostali wierni Bogu, niekiedy nawet ponosząc śmierć męczeńską (Dn 11,33-35; zob. też 7,21; 8,24-25; 1 Mch 1,57-63; 2 Mch 6,18-31; 7,1-42).

W odniesieniu do drugiej kategorii ludzi, autor Dn 12,2 stwierdza, że zmartwychwstaną do „do hańby, do odrazy wiecznej”, co w kontekście wypowiedzi o nagrodzie dla ludzi sprawiedliwych i wiernych Bogu należy rozumieć jako określenie kary. Warto zauważyć, że kara jest opisana dwoma terminami, mianowicie jako „hańba” (חרפות) oraz jako ,odraza wieczna” (דראון עולם). Termin ,odraza” (דראןן jest bardzo rzadki, gdyż pojawia się jeszcze tylko w Iz 66,24, gdzie jest mowa o sprawiedliwych przypatrujących się trupom bezbożnych: ,i zobaczą trupy ludzi, którzy zbuntowali się przeciwko Mnie, bo robak ich nie umrze i ogień ich nie zgaśnie, i będą odrazą (דראון) dla wszelkiego ciała". Na uwagę zasługuje także fakt, że termin ,hańba” (חרפות) z gramatycznego punktu widzenia jest w liczbie

8 Zob. A. Cowley, Gesenius' Hebrew Grammar as Edited and Enlarged by E. Kautzsch, Clarendon Press, Oxford 1910, s. 382 (§ 119w); P. Joüon, T. Muraoka, A Grammar of Biblical Hebrew (Subsidia Biblica, 14/2), Editrice Pontificio Istituto Biblico SubBi, Roma 2003, t. 2, s. 489 (§ 133e).

9 G.W.E. Nickelsburg, Resurrection, Immortality and Eternal Life, dz. cyt., s. 23; zob. też M. Hengel, Judaism and Hellenism, t. 1, dz. cyt., s. 200-201; M. Parchem, Księga Daniela, dz. cyt., 678. 
mnogiej, co może wyrażać intensywność i wielkość kary wymierzonej bezbożnym $^{10}$, co jest o tyle istotne, ponieważ autor Dn 12,2 nie wyjaśnia, na czym dokładnie będzie polegać kara wobec grzeszników, a jedynie stwierdza sam fakt ich ukarania ${ }^{11}$. Podobny motyw kary pojawia się w Regule zrzeszenia z Qumran, gdzie stwierdza się, że przeznaczeniem bezbożnych jest „wieczne zatracenie od mściwej zapalczywości gniewu Boga, dla przerażenia wiecznego i hańby na zawsze ze sromotą zniszczenia w ogniu ciemności” (1QS 4,11-14). Mając na uwadze kontekst całej wizji w Dn 10-12, można stwierdzić, że podmiotem „hańby i odrazy wiecznej" w Dn 12,2 są przede wszystkim ci, którzy zostali nazwani „zdrajcami świętego przymierza” (Dn 11,30), a więc są to zhellenizowani Żydzi, czyli apostaci.

Po opisie zmartwychwstania, które przybiera formę sądu, ponieważ w jego rezultacie wyraźnie wyodrębnia się dwie kategorie ludzi, z których jedna zostanie nagrodzona, a druga ukarana, w Dn 12,3 następuje opis wiecznego losu tych, którzy zasłużyli na nagrodę.

Uczestnikami nagrody polegającej na wywyższeniu są ,mędrcy” (המשכלים) oraz „ci, którzy uczynili sprawiedliwymi wielu” (מצדיק הרבים). Pierwsze z tych określeń, tj. המשכלים, jest imiesłowem w koniugacji hifil (od czasownika: שכל, ,rozumieć; mieć wgląd (w coś); być biegłym; inteligentnym”) i oznacza dosł. „tych, którzy uczynili mądrymi (kogoś)". Natomiast drugie określenie, tj. מצדיקי, stanowi imiesłów w koniugacji hifil (od czasownika צדק, ,być sprawiedliwym; usprawiedliwić”) i oznacza „tych, którzy uczynili sprawiedliwymi (kogoś)”. W obu przypadkach użycie sprawczej koniugacji hifil podkreśla, że chodzi o ludzi, którzy mieli wpływ na innych pełniąc funkcję przywódców ludu' ${ }^{12}$, a więc byli to „mędrcy”, tj. „ci, którzy uczyli mądrości”, „ci, którzy ułatwiali innym zrozumienie” oraz byli to „nauczyciele, którzy prowadzili innych w sprawiedliwości”, „ci, którzy nauczali

10 Liczba mnoga rzeczownika abstrakcyjnego często może wyraża intensywność, jakość lub stan rzeczywistości, którą przedstawia, zob. A. Cowley, Gesenius' Hebrew Grammar, dz. cyt., s. 398 (§ 124e); P. Joüon, T. Muraoka, A Grammar of Biblical Hebrew, t. 2, dz. cyt., s. 502 (§ 136g).

11 W Dn 12,3 jest mowa o nagrodzie polegającej na wywyższeniu mędrców / nauczycieli sprawiedliwości, ale nie wspomina się już o losie tych, którzy zmartwychwstaną „,do hańby, do odrazy wiecznej”, przez co autor Dn 12 wyraża przekonanie, że bezbożni nie będą uczestnikami ,życia wiecznego", zob. F. Zeilinger, Wiara w zmartwychwstanie w Biblii (Myśl Teologiczna, 69), tł. G. Rawski, Wydawnictwo WAM, Kraków 2011, s. 36.

12 Warto podkreślić, że w takiej roli występują w społeczności qumrańskiej (zob. np. 1QS 3,13; 9,12.21; por. 1QSb 1,1; 3,23; 5,20), zob. J.C. Trever, The Book of Daniel and the Origin of the Qumran Community, „The Biblical Archaeologist” 48 (1985), s. 97; więcej na ten temat, zob. P.R. Davies, The Scribal School of Daniel, w: The Book of Daniel. Composition and Reception (Vetus Testamentum Supplement, 83,1; Formation and Interpretation of Old Testament Literature, 2,1), red. J.J. Collins, P.W. Flint, Brill, Leiden 2001, t. 1, s. 247-265; C. Hempel, Maskil(im) and Rabbim: From Daniel to Qumran, w: Biblical Traditions in Transmission. Essays in Honour of Michael A. Knibb (Journal for the Study of Judaism. Supplement Series, 111), red. C. Hempel, J.M. Lieu, Brill, Leiden 2006, s. 133-156. 
innych sprawiedliwości”. Wydaje się, że w owych mędrcach i nauczycielach sprawiedliwości należy widzieć przede wszystkim tych, którzy czynią ludzi sprawiedliwymi poprzez ich nauczanie. Warto zauważyć, że w Dn 11,33 jest mowa o „mędrcach ludu” (משכילי עם), którzy ,uczyli wielu” (יבינו לרבים), dosł. ,ułatwiali / dawali zrozumienie wielu”. Wydaje się, że w „mędrcach”, którzy „uczynili sprawiedliwymi wielu" należy również widzieć tych, którzy przez swoje cierpienie i śmierć usprawiedliwiają innych, a więc ich męczeństwo wyraża myśl o cierpieniu zastępczym mającym wartość zbawczą, co jest tym bardziej uzasadnione, gdy uwzględni się istnienie w Dn 12 licznych aluzji do ostatniej „Pieśni o słudze JHWH" (Iz 52,13-53,12) $)^{13}$.

Opisując naturę nagrody autor Dn 12,3 stwierdza: „I mędrcy będą świecić jak blask firmamentu (כזהר הרקיע), a ci, którzy uczynili sprawiedliwymi wielu, jak gwiazdy (כפוכבים), na wieki i na zawsze". W przedstawieniu wywyższenia mędrców / nauczycieli sprawiedliwości, jako ich upodobnienie się do gwiazd, został wykorzystany motyw astralny, który jest obecny w tradycji biblijnej, a swoimi korzeniami sięga materiału mitologicznego starożytnego Bliskiego Wschodu i Grecji. W Biblii Hebrajskiej gwiazdy są identyfikowane jako istoty niebiańskie, które tworzą dwór JHWH w niebiosach (zob. Sdz 5,20; Hi 38,7; Dn 8,10). Autor Dn 12,3 nagrodę wywyższenia mędrców / nauczycieli sprawiedliwości ukazuje jako stan ich uczestnictwa we wspólnocie z istotami niebiańskimi ${ }^{14}$. Podobne przekonanie pojawia się w biblijnej Księdze Mądrości $(3,7 ; 5,5)$, w pismach o charakterze apokaliptycznym (np. List Henocha: 1 Hen 104,2-6; TestMojż 10,9; 4 Ezd 7,97.125; 2 Bar 51,10-12; zob. też 2 Hen 1,5; 66,7; Księga przypowieści: 1 Hen 51,4) oraz w Nowym Testamencie (Mk 12,25; Mt 22,30; Łk 20,36).

13 Np. Iz 52,13: „Oto powiedzie się (ישכיל) mojemu słudze” oraz Iz 53,11: „,sprawiedliwy mój sługa uczyni sprawiedliwymi (יצדיק) wielu", zob. A. Lacocque, The Book of Daniel, tt. D. Pellauer, John Knox Press, Atlanta 1979, s. 230; G.W.E. Nickelsburg, Resurrection, Immortality and Eternal Life, dz. cyt., s. 24-26; więcej na ten temat, zob. M. Hengel, D.P. Bailey, The Effective History of Isaiah 53 in the Pre-Christian Period, w: The Suffering Servant: Isaiah 53 in Jewish Christian Sources, red. B. Janowski, P. Stuhlmacher, William B. Eerdmans Publishing Company, Grand Rapids - Cambridge 2004, s. 91-92; G.B. Lester, Daniel Evokes Isaiah: Allusive Characterization of Foreign Rule in the Hebrew-Aramaic Book of Daniel (Library of Hebrew Bible. Old Testament Studies, 606), Bloomsbury, T \& T Clark, London - New York 2015, s. 94-99.

14 Zob. J.J. Collins, Apocalyptic Eschatology as the Transcendence of Death, „Catholic Biblical Quarterly” 36 (1974), s. 33-35; tenże, Daniel, dz. cyt., s. 393; A. Lacocque, The Book of Daniel, s. 244-245; L.F. Hartman, A.A. DiLella, The Book of Daniel. A New Translation with Introduction and Commentary (Anchor Bible, 23), Doubleday, New York 1978, s. 310; M. Hengel, Judaism and Hellenism, t. 1, dz. cyt., s. 196-197; H.C.C. Cavallin, Life after Death: Paul's Argument for the Resurrection of the Dead in 1 Cor 15 (Coniectanea biblica. New Testament Series, 7/1), Part 1: An Enquiry into the Jewish Background, Gleerup, Lund 1974, s. 27; M. Parchem, Ksiega Daniela, dz. cyt., 685-687; A. Chester, Future Hope and Present Reality, Eschatology and Transformation in the Hebrew Bible (Wissenschaftliche Untersuchungen zum Neuen Testament, 293), Mohr Siebeck, Tübingen 2012, t. 1, s. 292. 
Opis wydarzeń czasów ostatecznych w hymnicznym proroctwie eschatologicznym w Dn 12,1-3 kończy się stwierdzeniem, że ci, którzy pozostali wierni Bogu w okresie prześladowań, po śmierci będą wiecznie trwali razem z istotami niebiańskimi otaczającymi tron Boga w niebiosach. Autor Dn 12,3 z niezwykłą emfazą podkreśla zakres czasowy przyszłego losu mędrców / nauczycieli sprawiedliwości. Podczas gdy w w. 2 jest mowa o tym, że niektórzy zmartwychwstaną do ,życia wiecznego (עולם)", to w w. 3 o wywyższeniu stwierdza się, że taki stan zbawionych będzie trwać „na wieki i zawsze” (עולם וער).

\section{HYMNICZNE PROROCTWO ESCHATOLOGICZNE W „TESTAMENCIE MOJŻESZA” (TestMojż 10,1-10)}

Dokument noszący tytuł Testament Mojżesza zachował się tylko w jednym manuskrypcie łacińskim, pochodzącym z VI wieku po Chr. Tekst łaciński stanowi przekład z języka greckiego dokonany około $\mathrm{V}$ wieku po Chr., a ten jest thumaczeniem pisma, które powstało najprawdopodobniej w języku hebrajskim ${ }^{15}$. W obecnie istniejącej formie Testament Mojżesza może być datowany na wczesne lata I wieku po Chr., ale wielu uczonych przyjmuje, że powstanie dzieła przebiegało w dwóch etapach, mianowicie pierwotny dokument został napisany w czasach machabejskich (poł. II w. przed Chr.), a następnie został on uaktualniony i przepracowany na początku I wieku po Chr. ${ }^{16}$

15 Zob. np. R.H. Charles, The Assumption of Moses. Translated from the Latin Sixth Century Ms., the Unemended Text of which is Published herewith, together with the Text in its Restored and Critically Emended Form, London 1897, s. XXXVIII-XLV; M.E. Stone, Apocalyptic Literature, w: Jewish Writings of the Second Temple Period. Apocrypha, Pseudepigrapha, Qumran Sectarian Writings, Philo, Josephus (Compendia Rerum Iudaicarum ad Novum Testamentum, II/2), red. M.E. Stone, Van Gorcum, Assen - Fortress Press, Philadelphia 1984, s. 419; przegląd różnych hipotez na temat oryginalnego języka dokumentu, zob. E. Schürer, The History of the Jewish People, t. 3/1, dz. cyt., s. 284.

16 Zob. np. J. Licht, Taxo, or the Apocalyptic Doctrine of Vengeance, „Journal of Jewish Studies” 12 (1961), s. 95-103; G.W.E. Nickelsburg, An Antiochan Date for the Testament of Moses, w: Studies on the Testament of Moses: Seminar Papers (Septuagint and Cognate Studies Series, 4), red. G.W.E. Nickelsburg, Society of Biblical Literature, Cambridge 1973, s. 33-37; tenże, Jewish Literature between the Bible and the Mishnah: A Historical and Literary Introduction, Fortress Press, Minneapolis 2005, s. 74; J.J. Collins, The Apocalyptic Imagination, dz. cyt., s. 129; A. Yarbro Collins, Composition and Redaction of the Testament of Moses 10, „Harvard Theological Review” 69 (1976), s. 179-186; M. Parchem, Testament Mojżesza. Wprowadzenie, ttumaczenie i noty, w: Pisma apokaliptyczne i testamenty (Apokryfy Starego Testamentu, 2), red. M. Parchem, The Enigma Press, Kraków - Mogilany 2010, s. 308-309; więcej na temat kolejnych etapów powstawania Testamentu Mojżesza, zob. E. Schürer, The History of the Jewish People, t. 3/1, dz. cyt., s. 281-283; J.J. Collins, The Date and Provenance of the Testament of Moses, w: Studies on the Testament of Moses: Seminar Papers (Septuagint and Cognate Studies Series, 4), red. G.W.E. Nickelsburg, Society of Biblical Literature, Cambridge 1973, s. 17-30; O. Camponovo, Königtum, 
Pod względem formy Testament Mojżesza jest mową pożegnalną, którą Mojżesz przed swoją śmiercią kieruje do Jozuego, która została wygłoszona bezpośrednio przed wejściem do Kanaanu. Kompozycja całego utworu jest wzorowana na Księdze Powtórzonego Prawa, zaś na treść dokumentu składa się wprowadzenie (rozdz. 1), główna część dzieła, gdzie w formie przemówienia Mojżesza zostały ukazane dzieje Izraela, począwszy od zajęcia Ziemi Obiecanej aż po czasy ostateczne (rozdz. 2-9), a całość kończy dialog Mojżesza z Jozuem (rozdz. 11-12). Eschatologiczne proroctwo mające formę hymnu (10,1-10) stanowi zakończenie przemowy i dotyczy wydarzeń czasów ostatecznych.

Treść proroctwa w TestMojż 10,1-10 przedstawia się następująco:

1 A wtedy Jego królestwo ukaże się w catym Jego stworzeniu;

$i$ wtedy diabta spotka koniec

i smutek zniknie wraz z nim.

2 Wtedy zostana napetnione ręce zwiastuna, namaszczonego w najwyższym (miejscu), który dokona zemsty na ich wrogach.

3 Ponieważ Niebianin powstanie ze swego królewskiego tronu, $i$ wyjdzie ze swego świętego mieszkania, z zapalczywościa i gniewem z powodu swoich synów.

4 I ziemia zadrży, i będzie wstrzaśnięta aż do najdalszych krańców; $i$ wysokie góry zostana obniżone $i$ wstrzaśnięte, a doliny upadna.

5 Stońce nie da światta; rogi księżyca obróca się w ciemność, zostana roztrzaskane w kawałki, i wszystkie obróca się w krew; i bieg gwiazd zostanie zaktócony.

6 I morze zejdzie aż do otchtani; i źródła wód zanikna; i rzeki wyschna.

7 Ponieważ Najwyższy powstanie, jedyny wieczny Bóg; i objawi się, aby ukarać narody pogańskie, i zniszczy wszystkie ich bozkki.

Königsherrschaft und Reich Gottes in den frühjüdischen Schriften (Orbis biblicus et orientalis, 58), Universitätsverlag, Freiburg (Schweiz) - Vandenhoeck und Ruprecht, Göttingen 1984, s. 151-158;

D. Maggiorotti, La datazione del Testamento di Mosè, „Henoch” 15 (1993), s. 235-262. 
$8 \quad$ Wtedy będziesz szczęśliwy, o Izraelu!

Wstapisz na kark i skrzydła orła;

ponieważ czas im przyznany zakończy swój bieg.

9 I wywyższy cię Bóg,

i umieści cię na stałe w niebie gwiazd,

w miejscu ich zamieszkania.

10 I spojrzysz z wysokości

i zobaczysz twoich wrogów na ziemi.

I poznajac ich, rozradujesz się,

i podziękujesz, i uznasz swego Stwórcę.

Opisane przez autora TestMojż 10,1-10 wydarzenia czasów ostatecznych są ukazane jako interwencja Boga, która nastąpi w reakcji na śmierć tych, którzy w prześladowaniach okazali się Jemu wierni (zob. 9,6-7: „,raczej umrzyjmy, aniżeli mielibyśmy przekroczyć przykazania Pana panów, Boga naszych ojców. Bo jeśli to uczynimy i umrzemy, nasza krew zostanie pomszczona przez Pana"). Po ogólnym wprowadzeniu (ww. 1-2), działanie Boga jest ukazane za pomocą terminologii używanej w opisach teofanii (ww. 3-6), którego rezultatem będzie ukaranie narodów pogańskich (w. 7) oraz wywyższenie Izraela (ww. 8-10).

Treść ww. 1-2 stanowi wprowadzenie do całego hymnu, w którym wydarzenia czasów ostatecznych zostały ogólnie ujęte w wymiarze pozytywnym, tj. ustanowienia królestwa Bożego, jak również negatywnym, tj. unicestwienia diabła i smutku, czyli zła.

Słowa „Jego królestwo ukaże się w całym Jego stworzeniu” wyrażają prawdę o tym, że królewska władza Boga zostanie objawiona w całym wszechświecie (zob. też 3 Syb 47-48; 2 Bar 39,7). Wyrażenie „Jego królestwo” (regnum illius) jest tutaj synonimem potęgi, siły i majestatu Boga, który jest jedynym i najwyższym Królem zasiadającym na niebiańskim tronie (zob. 4,2) ${ }^{17}$. Królewską władzę Boga, która swoim zasięgiem obejmuje niebiosa i ziemię, wyrażają tytuły: Caelestis, „Niebianin”, tj. „Ten, który przebywa w niebiosach” (w. 3), Summus, „Najwyższy” oraz Deus aeternus solus, ,jedyny wieczny Bóg” (w. 7).

Rezultatem objawienia się Boga w potędze Jego królewskiej władzy jest unicestwienie diabła: „i wtedy diabła spotka koniec” (et tunc zabulus ${ }^{18}$ finem habebit). Wzmianka o unicestwieniu diabła uwypukla absolutną władzę Boga, który usta-

17 Zob. P. Volz, Die Eschatologie der jüdischen Gemeinde, dz. cyt., s. 167-169; J. Tromp, The Assumption of Moses. A Critical Edition with Commentary (Studia in Veteris Testamenti Pseudepigrapha, 10), Brill, Leiden 1993, s. 229; por. TestMojż 4,2: „Panie, Królu wszystkiego na wyniosłym tronie (Domine, omnis rex in alta sede), który władasz światem”; TestMojż 2,4: Deus caelestis, „Bóg niebios”; TestMojż 4,4: Dominus caelestis, „Pan niebios”.

18 Forma zabulus jest ortograficznym wariantem słowa diabolus (por. gr. $\delta\llcorner\alpha \beta 0 \lambda \circ \varsigma)$ ); ten sam wariant pojawia się w napisanym na początku IV w. dziele pisarza chrześcijańskiego Laktancjusza (De mortibus persecutorum, 16), zob. C.T. Lewis, C. Short, A Latin Dictionary Founded on Andrews' 
nawiając swoje królestwo niszczy wszelkie wrogie siły (zob. Jub 23,29; 50,5) ${ }^{19}$. $\mathrm{Z}$ drugiej strony, mając na uwadze sugestię, że w całym hymnie jest dużo aluzji do procesu sądowego ${ }^{20}$, unicestwienie diabła może oznaczać wydalenie go z niebiańskiego dworu Boga i pozbawienie go możliwości sprawowania funkcji oskarżyciela, którą tam pełnił (por. Hi 1,6-12; 2,1-7) ${ }^{21}$.

Razem z diabłem zostanie unicestwiony ,smutek” (tristitia), który jest jego dziełem (por. 1 Jn 3,8: „Syn Boży objawił się, aby zniszczyć dzieła diabła”). Motyw smutku być może jest tutaj rozumiany jako rozpacz i cierpienie wywołane plagami i nieszczęściami, które dotknęły Izraela z powodu jego grzechów. Autor TestMojż stwierdzając, że „smutek zniknie wraz z nim (tj. z diabłem)” (w. 1) wyraża przekonanie, że ustanowienie królestwa Bożego sprawi, że smutek zostanie zamieniony w radość (w. 10). Podobny motyw często pojawia się zarówno w pismach żydowskich, jak i w tradycji chrześcijańskiej (zob. np. Jub 23,29; 4 Ezd 6,27; 2 Bar 73,1-4; 5 Syb 385; TestJud 25,4; J 16,20; Ap 21,4; por. Iz 35,10; 51,11).

W w. 2 pojawia się istota niebiańska określona jako ,zwiastun, posłaniec, anioł” (nuntius; gr. $\alpha \gamma \gamma \in \lambda$ os), którą najprawdopodobniej należy identyfikować z Micha$ł^{22}$, patronem i obrońcą Izraela (zob. Dn 10,13.21; 12,1; 1 Hen 47,2; 1QM 17,6-7; TestLew 3,3). Rola Michała w TestMojż 10 polega na pełnieniu dwóch funkcji. $\mathrm{Z}$ jednej strony przypisuje się mu funkcje kapłańskie i przedstawia się go jako orędownika pełniącego rolę wstawienniczą, na co wskazują słowa ,zostaną napełnione ręce zwiastuna" (implebuntur manus nuntii). Co więcej, zwiastun pełni swoją funkcję w niebiosach, o czym wyraźnie świadczy wzmianka o namaszczeniu go

Edition of Freund's Latin Dictionary, Revised, Enlarged, and in Great Part Rewritten, Clarendon Press, Oxford 1958, s. 2018 (pierwsza edycja: Oxford 1879).

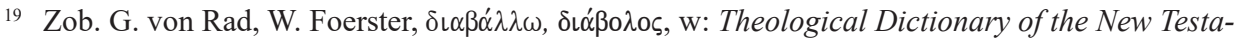
ment, red. G. Kittel, tł. G.W. Bromiley, William B. Eerdmans Publishing Company, Grand Rapids 1993, t. 2, s. 78; J. Tromp, The Assumption of Moses, dz. cyt., s. 229; M. Parchem, Testament Mojżesza, dz. cyt., s. 333.

20 Jurydyczny charakter hymnu w TestMojż 10 podkreśla zwłaszcza G.W.E. Nickelsburg (Resurrection, Immortality, and Eternal Life, dz. cyt., s. 29-31), który nazywa go „sceną sądową”.

21 Zob. J. Becker, Das Heil Gottes. Heils- und Sündenbegriffe in den Qumrantexten und im Neuen Testament (Studien zur Umwelt des Neuen Testaments, 3), Vandenhoeck und Ruprecht, Göttingen 1964, s. 100-101; por. O. Camponovo, Königtum, Königsherrschaft und Reich Gottes, dz. cyt., s. 170.

22 Tak m.in. R.H. Charles, The Assumption of Moses, dz. cyt., s. 39-40; tenże, The Assumption of Moses, w: The Apocrypha and Pseudepigrapha of the Old Testament, red. R.H. Charles, i in., Clarendon Press, Oxford 1913, t. 2, s. 421; J. Gray, The Biblical Doctrine of the Reign of God, T \& T Clark Ltd, Edinburgh 1979, s. 254; J.J. Collins, The Testament (Assumption) of Moses, w: Outside the Old Testament (Cambridge Commentaries on Writings of the Jewish and Christian World 200 BC to AD 200, 4), red. M. de Jonge, Cambridge University Press, Cambridge 1985, s. 156; J. Priest, Testament of Moses (First Century A.D.). A New Translation and Introduction, w: The Old Testament Pseudepigrapha, Apocalyptic Literature and Testaments, red. J.H. Charlesworth, i in., Doubleday, New York 1983, t. 1, s. 932; E.-M. Laperrousaz, Testament de Moïse, w: La Bible: Ecrits Intertestamentaires, red. A. Dupont-Sommer, M. Philonenko, Gallimard, Paris 1987, s. 1010; M. Parchem, Testament Mojżesza, dz. cyt., s. 333. 
„W najwyższym miejscu” (qui est in summo constitutus). Wyrażenie „napełnić ręce" jest technicznym określeniem konsekracji na kapłana (zob. np. Wj 28,41; 29,29.33.35; Kpł 8,33; 16,32; 21,10; Lb 3,3; Sdz 17,5.12; 1 Krl 13,33; 2 Krn 13,9; TestLew 8,10; JzfAs 27,2). W wielu pismach z okresu Drugiej Świątyni pojawia się motyw działalności kapłańskiej istot niebiańskich polegającej na wstawiennictwie (np. Tb 12,12.15; 1 Hen 9,1-4.10-11; 10,13; 99,3; 3 Bar 11-16). Warto zauważyć, że w 3 Bar 11-16 został ukazany Michał jako najwyższy dowódca i strażnik kluczy niebios, który pełni funkcję pośrednika, co jest ukazane w ten sposób, że trzyma on w rękach ogromną czarę wypełnioną cnotami i dobrymi czynami sprawiedliwych, którą następnie wnosi do Boga. W TestMojż zwiastun jest tym, który wysłuchuje wołania o sprawiedliwość prześladowanych i ponoszących śmierć męczeńską $(9,6-7)$ i przedstawia je Bogu, który zostaje w ten sposób skłoniony do interwencji i pomszczenia przelanej krwi (zob. też 10,3: Bóg objawi się ,Z zapalczywością i gniewem z powodu swoich synów” $)^{23}$.

$\mathrm{Z}$ drugiej strony zwiastun jest tym, „który dokona zemsty (dosł. pomści ich) na ich wrogach" (vindicabit illos ab inimicis eorum). Jego funkcja ma charakter zarówno militarny, ponieważ rezultatem jego działalności prowadzonej w imieniu Boga będzie unicestwienie wszystkich wrogów, jak również zawiera konotacje jurydyczne, gdyż łacińskie wyrażenie vindicare ... $a b$, ,„dokonać zemsty nad (kimś)” może oznaczać „wysuwać roszczenia, uwolnić, wybawić”24. Połączenie działalności o charakterze militarnym i jurydycznym, którą prowadzi zwiastun (nuntius) w TestMojż 10,2, jest bardzo podobne do funkcji, którą pełni Michał w Dn 12,1.

Występujący w ww. 3-6 opis interwencji Boga w czasach eschatologicznych nawiązuje do języka znanego $\mathrm{z}$ opisów teofanii pojawiających się $\mathrm{w}$ tradycji biblijnej (np. Wj 19,16-20; Pwt 33,2-3; Sdz 5,4-5; Ps 18,8-16; 29,3-9; 68,8-9; 77,17-20; 97,3-6; Iz 30,27-33; Mi 1,3-7; Ha 3,3-15; zob. też 1 Hen 1,3-9). W opisach teofanii zwykle występują dwa połączone ze sobą wydarzenia, mianowicie „przybycie” Boga oraz poruszenie natury, które przybiera formę różnego rodzaju kataklizmów o zasięgu kosmicznym, między innymi burza, grzmoty, błyskawice, trzęsienie ziemi, wzburzenie wód ${ }^{25}$.

${ }^{23}$ Zob. G. Kuhn, Zur Assumptio Mosis, „Zeitschrift für die alttestamentliche Wissenschaft” 43 (1925), s. 126; O. Camponovo, Königtum, Königsherrschaft und Reich Gottes, dz. cyt., s. 170; D.C. Carlson, Vengeance and Angelic Mediation in Testament of Moses 9 and 10, „Journal of Biblical Literature" 101 (1982), s. 85-95.

24 Zob. G.W.E. Nickelsburg, Resurrection, Immortality, and Eternal Life, dz. cyt., s. 29; O. Camponovo, Königtum, Königsherrschaft und Reich Gottes, dz. cyt., s. 171.

25 Szerzej na ten temat, zob. J. Jeremias, Theophanie. Die Geschichte einer alttestamentlichen Gattung (Wissenschaftliche Monographien zum Alten und Neuen Testamenten, 10), Neukirchener Verlag, Neukirchen-Vluyn 1965; H. Witczyk, Teofania w Psalmach, Polskie Towarzystwo Teologiczne, Kraków 1985; T. Hiebert, Theophany in the OT, w: The Anchor Bible Dictionary, red. D.N. Freedman, i in., Doubleday, New York 1992, t. 6, s. 505-511; zob. też M. Parchem, 
Objawienie się Boga (w. 3) autor TestMojż opisuje za pomocą czasowników wyrażających ruch: „powstanie ze swego królewskiego tronu” (exurget ... a sede regni sui) oraz „wyjdzie ze swego świętego mieszkania” (exiet de habitatione sancta sua). Bez wątpienia w obydwu wyrażeniach miejscem, z którego wychodzi Bóg, są niebiosa jako miejsce Jego stałego przebywania (zob. np. Pwt 26,15; $1 \mathrm{Krl} \mathrm{8,30;} \mathrm{Iz} \mathrm{26,21;} \mathrm{63,15;} \mathrm{Jr} \mathrm{25,30;} \mathrm{Am} \mathrm{1,2;} \mathrm{Mi} \mathrm{1,3;} \mathrm{Ha} \mathrm{3,3;} \mathrm{Za} \mathrm{2,13;} \mathrm{zob.} \mathrm{też}$ 1 Hen 14,8-23).

W ww. 4-6 znajduje się opis zachwiania porządku istniejącego w kosmosie, a więc naruszenia naturalnych praw rządzących całym wszechświatem, co przejawia się w katastrofach i różnego rodzaju kataklizmach o zasięgu kosmicznym, które towarzyszą objawiającemu się Bogu. Jak zauważa J. Jeremias, większość z nich należy do typowych elementów opisów teofanijnych, ale wzmianka o zakłóceniu funkcjonowania słońca, księżyca i gwiazd należy do tradycji związanej z koncepcją „dnia JHWH” (zob. Iz 13,10; Jl 2,10; 3,4; 4,15; zob. też Mk 13,24; Mt 24,29), co świadczy o tym, że w TestMojż 10,4-6 - podobnie jak w Ha 3,10-11 zostały połączone motywy pochodzące z tradycji o teofanii oraz dnia $\mathrm{JHWH}^{26}$. Można przypuszczać, że opis kataklizmów o zasięgu kosmicznym występujący w TestMojż 10,4-6 7 może być traktowany jako nawiązanie i swoistego rodzaju ekwiwalent „czasu ucisku”, o którym mowa w Dn 12,1. Jeśli ta sugestia byłaby słuszna, to w opisie czasów ostatecznych w TestMojż 10 myśl o ucisku ze strony narodów pogańskich (gentes), o czym jest mowa w w. 7, została wzbogacona o motyw kataklizmów nabierających cech kosmicznych (ww. 4-6). Warto zwrócić uwagę, że w wielu opisach ucisków stanowiących początek czasów eschatologicznych następuje połączenie motywu zachwiania porządku kosmicznego z niepokojami i konfliktami społeczno-politycznymi (np. 4 Ezd 5,1-13; 2 Bar 23,5-27,15; zob. też Mk 13,7-25; Mt 24,6-29; Łk 21,9-26). W TestMojż 10 pojawia się sekwencja wydarzeń podobna do tej, która występuje w Dn 12,1-3, mianowicie po okresie ucisku, który TestMojż obejmuje prześladowanie ze strony narodów pogańskich oraz kataklizmy o charakterze kosmicznym, nastąpi ostateczna interwencja Boga, której rezultatem będzie wybawienie sprawiedliwych i nagroda polegająca na ich wywyższeniu.

Interwencja Boga posiada w TestMojż 10 dwa aspekty: negatywny i pozytywny. W aspekcie negatywnym konsekwencją objawienia się Boga będzie ukaranie „narodów pogańskich (gentes)” oraz,,wszystkich ich bożków (omnia idola eorum)” (w. 7). Łaciński termin idolum lub idolon (gr. $\epsilon \_\omega \lambda \mathrm{\lambda} \nu$ ) oznacza materialne wyobrażenie bóstwa (posąg, obraz), wizerunek / podobiznę bóstwa ${ }^{27}$. Wydaje się, że tutaj

Teofania w 1 Hen 1,3c-9 w kontekście tradycji biblijnej, w: Studia z biblistyki, red. R. Bartnicki, Wydawnictwo Uniwersytetu Kardynała Stefana Wyszyńskiego, Warszawa 2012, t. 8, s. 73-108.

26 J. Jeremias, Theophanie, dz. cyt., s. 98; zob. też O. Camponovo, Königtum, Königsherrschaft und Reich Gottes, dz. cyt., s. 167; J. Tromp, The Assumption of Moses, dz. cyt., s. 234.

27 Zob. C.T. Lewis, C. Short, A Latin Dictionary, dz. cyt., s. 878. 
słowo „bożki” (idola) stanowi również określenie bóstw czczonych przez narody pogańskie, w którym kryje się swoistego rodzaju ironia wskazująca na głupotę tych, którzy uznają za bóstwa i czczą przedmioty uczynione przez samych siebie. W ten sposób autor TestMojż potęgę jedynego i wiecznego Boga przeciwstawia zniszczalnym bożkom pogańskim. Motyw zniszczenia pogańskich bożków pojawia się również w opisie teofanii w Mi 1,3-7: „I wszystkie jej (tj. Samarii) bożki (LXX: $\tau \alpha \gamma \lambda \cup \pi \tau \alpha$; Wlg: sculptilia) będą rozbite, i wszystkie jej podarunki zostaną spalone w ogniu, i wszystkie jej podobizny (LXX: $\tau \alpha \epsilon \iota \delta \omega \lambda \alpha$; Wlg: idola) uczynię pustkowiem" (w. 7; zob. też Mdr 14,11; 1 Hen 91,9; 3 Syb 618).

$\mathrm{W}$ aspekcie pozytywnym rezultatem objawienia się Boga jest wybawienie Izraela, co autor TestMojż 10 wyraża w słowach: „Wtedy będziesz szczęśliwy, o Izraelu!" (tunc felix eris tu, Israhel)" (w. 8; por. Pwt 33,29). Szczęście Izraela wynika nie tylko z powodu unicestwienia jego wrogów: „ponieważ czas im przyznany zakończy swój bieg” (por. wzmiankę o diable, którego „spotka koniec” w w. 1), ale przede wszystkim z opieki, którą Bóg roztacza nad swoim ludem, co wyraża obraz niesienia przez orła: „Wstąpisz na kark i skrzydła orła”. Ten motyw może nawiązywać do obecnego w tradycji biblijnej obrazu, w którym Izrael niesiony na skrzydłach orła jest wyrażeniem prawdy o trosce i ochronie Boga w kontekście wyjścia z Egiptu (Wj 19,4; Pwt 32,11). Należy jednak zauważyć, że w TestMojż 10,8 wzmianka o orle zawiera myśl o tym, że Bóg w czasach eschatologicznych zapewni Izraelowi bezpieczeństwo poprzez wyniesienie go na skrzydłach orła na wysokości niebios, aby stamtąd mógł zobaczyć klęskę swoich wrogów. Innymi słowy, wyniesienie Izraela na skrzydłach orła ku niebiosom jest wyrażeniem prawdy o jego wywyższeniu w czasach ostatecznych, którego dokona Bóg, o czym wyraźnie jest mowa w w. 9. Podobna myśl, która pojawia się w kontekście ochrony sprawiedliwych przed bezbożnymi, znajduje się w Liście Henocha: „W dniu, w którym przyjdzie ucisk na grzeszników, wasze potomstwo powstanie i uniesie się jak orły, a wasze gniazda będą wyżej od gniazd sępów" (1 Hen 96,2). Wzmianka o orłach wyraża prawdę o tym, że sprawiedliwi będą obdarzeni siłą, dzięki której zostaną ocaleni z niebezpieczeństwa zagrażającego im ze strony bezbożnych (tj. sępów), co bez wątpienia jest nawiązaniem do Iz 40,31: „I ci, którzy ufają JHWH, odzyskują siłę, wznoszą skrzydła jak orły"28.

Opis wywyższenia Izraela w TestMojż 10,9, które jest ukazane jako umieszczenie go w niebie gwiazd: „, umieści cię na stałe w niebie gwiazd, w miejscu ich zamieszkania" (et faciet te herere caelo stellarum, loco habitationis eorum) jest typowym elementem oczekiwań eschatologicznych nawiązującym do Dn 12,3 (zob. 4 Ezd 7,97.125; 2 Bar 51,5; 1 Hen 51,4; 104,2; LAB 19,9; 33,5; TestLew

28 Zob. R.H. Charles, The Assumption of Moses, dz. cyt., s. 42; E.M. Laperrousaz, Le Testament de Moïse, dz. cyt., s. 1012; O. Camponovo, Königtum, Königsherrschaft und Reich Gottes, dz. cyt., s. 168; J. Tromp, The Assumption of Moses, dz. cyt., s. 236; L.T. Stuckenbruck, 1 Enoch 91-108 (Commentaries on Early Jewish Literature), Walter de Gruyter, Berlin - New York 2007, s. 288. 
$14,3 ; 18,4)$. Trudno jednoznacznie stwierdzić, czy autor TestMojż rozumie tu gwiazdy w sensie dosłownym, tj. jako ciała niebiańskie, czy też w sensie metaforycznym, tj. jako istoty niebiańskie. Wydaje się, że termin „gwiazdy” (stellae, rodzaj żeński) występuje tutaj jako określenie istot niebiańskich (angeli; gr. $\alpha \gamma \gamma \in \lambda$ ol, rodzaj męski), na co wskazuje zaimek osobowy rodzaju męskiego „ich” (eorum) użyty na oznaczenie miejsca zamieszkania gwiazd. Warto zwrócić uwagę na fakt, że w Dn 12,2-3 wywyższenie i uczestnictwo we wspólnocie z istotami niebiańskimi (w. 3), będzie miało miejsce po zmartwychwstaniu (w. 2), przy czym nie pojawia się tutaj termin na określenie samego wywyższenia, lecz jedynie w w. 1 stwierdza się, że ,zostanie ocalony twój naród (tj. Izrael)”. Natomiast w TestMojż 10,9-10 nie wspomina się wprost o zmartwychwstaniu, ale w w. 9 wyraźnie jest mowa o wywyższeniu: „i wywyższy cię Bóg” (et altavit te Deus).

Podczas gdy w Dn 12,3 podkreśla się, że natura wywyższenia mędrców / nauczycieli sprawiedliwości będzie polegać na ich upodobnieniu się do gwiazd, tj. istot niebiańskich („,będą świecić jak blask firmamentu (...), jak gwiazdy”), to w TestMojż 10,9 uwypukla się motyw przebywania Izraela wśród gwiazd, aby z wysokości nieba móc oglądać klęskę swoich wrogów. W tradycji biblijnej niebiosa są miejscem zamieszkania Boga, który stamtąd spogląda na ziemię i jej mieszkańców: „Z niebios patrzy JHWH, widzi wszystkich synów ludzkich. Z miejsca, gdzie przebywa, spogląda na wszystkich mieszkańców ziemi" (Ps 33,13-14; zob. też Pwt 26,15; Iz 63,15; Ps 102,20; 113,5-6). Według TestMojż 10,9-10, wywyższony Izrael, który został wyniesiony do niebios i stał się uczestnikiem wspólnoty z istotami niebiańskimi, będzie mógł również spoglądać na ziemię, aby zobaczyć ostateczne zniszczenie zła (w. 7). Warto zwrócić uwagę na podobny w swej wymowie tekst z Listu Henocha: „Ufajcie! Bo jak wcześniej zostaliście upokorzeni przez zło i ucisk, tak teraz zajaśniejecie jak światła niebios, będziecie świecić i będziecie widziani, a bramy niebios zostaną przed wami otwarte (...). Ufajcie i nie porzucajcie waszej nadziei, bo będziecie mieć radość wielką jak aniołowie w niebiosach (...), nie łączcie się z nimi (tj. grzesznikami), ale trzymajcie się z daleka od ich złych czynów, bo zostaniecie dołączeni do zastępu niebios" (1 Hen 104,2-6; zob. też 1 Hen 39,3-8; 41,1-2; 2 Bar 51,5.10.12) ${ }^{29}$.

Hymniczne proroctwo eschatologiczne w TestMojż 10 kończy się wzmianką o radości wywyższonego Izraela, który składa dziękczynienie Bogu za swoje wybawienie. Motyw radości ocalonych, która jest spowodowana karą wymierzoną wrogom, pojawia się w tradycji biblijnej i w literaturze okresu Drugiej Świątyni (zob. np. Iz 66,14; 1 Hen 62,12; Jub 23,30), a według 1 Hen 97,2 nawet aniołowie będą radować się z ukarania grzeszników.

29 Zob. R.H. Charles, The Assumption of Moses, dz. cyt., s. 43; E.M. Laperrousaz, Le Testament de Moïse, dz. cyt., s. 1012; J. Tromp, The Assumption of Moses, dz. cyt., s. 237. 


\section{PODSUMOWANIE}

Hymniczne proroctwa eschatologiczne znajdujące się w biblijnej Księdze Daniela (Dn 12,1-3) oraz w apokryficznym Testamencie Mojżesza (TestMojż 10,1-10) pełnią ważną funkcję w kompozycji obu dokumentów. W Księdze Daniela jest punktem kulminacyjnym wizji apokaliptycznej w Dn 10-12, której treścią jest historia Izraela, począwszy od epoki perskiej, poprzez okres hellenistyczny, zwłaszcza panowanie Antiocha Epifanesa, aż po czasy ostateczne. Natomiast w Testamencie Mojżesza stanowi zakończenie mowy pożegnalnej (TestMojż 2-10), w której Mojżesz tuż przed swoją śmiercią przedstawia dzieje Izraela od wejścia do Kanaanu aż po czasy eschatologiczne. Chociaż w obydwu hymnach nie przedstawia się ściśle usystematyzowanego przebiegu wydarzeń w czasach ostatecznych, to jednak można w nich wyodrębnić pewne elementy, które układają się w schemat zawierający swoistego rodzaju „etapy” tych zdarzeń, co w późniejszych pismach o charakterze apokaliptycznym - zarówno żydowskich, jak i chrześcijańskich stało się niemal standardowym sposobem ujmowania tematyki dotyczącej tego, co stanie się ,przy końcu dni” (zob. Dn 2,28; TestMojż 1,18).

W Księdze Daniela początek wydarzeń eschatologicznych został ukazany jako „czas ucisku” (w. 1), czyli okres prześladowań ludzi wiernych Bogu, ale również ich wybawienia, gdyż w obronie sprawiedliwych wystąpi Michał, obrońca i opiekun Izraela. Okres ucisku jest momentem w historii, gdy z niespotykaną jak dotąd intensywnością uaktywniają się siły zła, stąd dla ludzi jest to również czas próby. Po tym wydarzeniu nastąpi zmartwychwstanie, ukazane za pomocą metafory obudzenia się ze snu, które posiada równocześnie znamiona sądu, ponieważ niektórzy obudzą się „do życia wiecznego”, a niektórzy „do hańby, do odrazy wiecznej” (w. 2). Hymniczne proroctwo kończy się opisem wiecznego losu zbawionych, a więc ich wywyższenia, które będzie polegać na uczestnictwie we wspólnocie z istotami niebiańskimi (w. 3).

W Testamencie Mojżesza wydarzenia eschatologiczne zostają najpierw ukazane w formie ogólnego stwierdzenia, że będzie to czas ustanowienia królestwa Bożego i unicestwienia diabła, czyli wszystkich sił zła, w czym aktywną rolę będzie pełnić postać anioła, który najprawdopodobniej powinien być identyfikowany z Michałem (ww. 1-2). Następnie pojawia się opis naruszenia naturalnego porządku istniejącego w świecie, co przejawia się w występujących z niezwykłym natężeniem różnego rodzaju kataklizmów o zasięgu kosmicznym (ww. 3-6). Wykorzystując język opisów teofanijnych zostaje ukazana interwencja Boga, której rezultatem jest ostateczne pokonanie wrogich sił (w. 7) oraz wywyższenie Izraela i włączenie go do uczestnictwa we wspólnocie z istotami niebiańskimi (ww. 8-9). Eschatologiczny hymn kończy się wzmianką o radości wywyższonego Izraela z wybawienia oraz jego dziękczynieniu składanemu Bogu za Jego dobrodziejstwa. (w. 10). 
W obydwu hymnicznych proroctwach eschatologicznych uwypukla się pełne nadziei przesłanie wypływające z opisywanych wydarzeń, a jest nim niezachwiana pewność w ostateczne zwycięstwo dobra oraz w opiekę Boga, który zawsze troszczy się o sprawiedliwych, a kiedyś za wierność, którą okazali w czasie próby, wywyższy ich i wprowadzi do niebios, gdzie we wspólnocie z istotami niebiańskimi będą wielbić Go bez końca.

\section{Bibliografia}

Becker J., Das Heil Gottes. Heils- und Sündenbegriffe in den Qumrantexten und im Neuen Testament (Studien zur Umwelt des Neuen Testaments, 3), Vandenhoeck und Ruprecht, Göttingen 1964.

Camponovo O., Königtum, Königsherrschaft und Reich Gottes in den frühjüdischen Schriften (Orbis biblicus et orientalis, 58), Universitätsverlag, Freiburg (Schweiz) - Vandenhoeck und Ruprecht, Göttingen 1984.

Carlson D.C., Vengeance and Angelic Mediation in Testament of Moses 9 and 10, „Journal of Biblical Literature” 101 (1982), s. 85-95.

Cavallin H.C.C., Life after Death: Paul's Argument for the Resurrection of the Dead in 1 Cor 15 (Coniectanea biblica. New Testament Series, 7/1), Part 1: An Enquiry into the Jewish Background, Gleerup, Lund 1974.

Charles R.H., The Assumption of Moses, w: The Apocrypha and Pseudepigrapha of the Old Testament, red. R.H. Charles, i in., Clarendon Press, Oxford 1913, t. 2, s. 407-424.

Charles R.H., The Assumption of Moses. Translated from the Latin Sixth Century Ms., the Unemended Text of which is Published herewith, together with the Text in its Restored and Critically Emended Form, Adam and Charles Black, London 1897.

Chester A., Future Hope and Present Reality, Eschatology and Transformation in the Hebrew Bible (Wissenschaftliche Untersuchungen zum Neuen Testament, 293), Mohr Siebeck, Tübingen 2012, t. 1.

Collins J.J., Apocalyptic Eschatology as the Transcendence of Death, „Catholic Biblical Quarterly" 36 (1974), s. 21-43.

Collins J.J., Daniel: A Commentary on the Book of Daniel (Hermeneia), Fortress Press, Minneapolis 1993.

Collins J.J., The Apocalyptic Imagination: An Introduction to Jewish Apocalyptic Literature (The Biblical Resource Series), William B. Eerdmans Publishing Company, Grand Rapids - Cambridge 1998.

Collins J.J., The Apocalyptic Vision of the Book of Daniel (Harvard Semitic Monographs, 16), Scholars Press, Missoula 1977. 
Collins J.J., The Date and Provenance of the Testament of Moses, w: Studies on the Testament of Moses: Seminar Papers (Septuagint and Cognate Studies Series, 4), red. G.W.E. Nickelsburg, Society of Biblical Literature, Cambridge 1973, s. 17-30.

Collins J.J., The Testament (Assumption) of Moses, w: Outside the Old Testament (Cambridge Commentaries on Writings of the Jewish and Christian World 200 BC to AD 200, 4), red. M. de Jonge, Cambridge University Press, Cambridge 1985 , s. $145-158$.

Cowley A., Gesenius'Hebrew Grammar as Edited and Enlarged by E. Kautzsch, Clarendon Press, Oxford 1910.

Davies P.R., The Scribal School of Daniel, w: The Book of Daniel. Composition and Reception (Vetus Testamentum Supplement, 83,1; Formation and Interpretation of Old Testament Literature, 2,1), red. J.J. Collins, P.W. Flint, Brill, Leiden 2001 , t. 1 , s. $247-265$.

Gray J., The Biblical Doctrine of the Reign of God, T \& T Clark Ltd, Edinburgh 1979.

Hartman L.F., A.A. DiLella, The Book of Daniel. A New Translation with Introduction and Commentary (Anchor Bible, 23), Doubleday, New York 1978.

Hempel C., Maskil(im) and Rabbim: From Daniel to Qumran, w: Biblical Traditions in Transmission. Essays in Honour of Michael A. Knibb (Journal for the Study of Judaism. Supplement Series, 111), red. C. Hempel, J.M. Lieu, Brill, Leiden 2006, s. 133-156.

Hengel M., Judaism and Hellenism: Studies in their Encounter in Palestine during the Early Hellenistic Period, tt. J. Bowden, SCM Press Ltd, London 1996, t. $1-2$.

Hengel M., D.P. Bailey, The Effective History of Isaiah 53 in the Pre-Christian Period, w: The Suffering Servant: Isaiah 53 in Jewish Christian Sources, red. B. Janowski, P. Stuhlmacher, William B. Eerdmans Publishing Company, Grand Rapids - Cambridge 2004, s. 75-146.

Hiebert T., Theophany in the OT, w: The Anchor Bible Dictionary, red. D.N. Freedman, i in., Doubleday, New York 1992, t. 6, s. 505-511.

Illman K.-J., H. Ringgren, H.-J. Fabry, mût, et al., w: Theological Dictionary of the Old Testament, red. G.J. Botterweck, H. Ringgren, H.-J. Fabry, tł. D.W. Stott, William B. Eerdmans Publishing Company, Grand Rapids - Cambridge 1997, t. VIII, s. 185-209.

Jeremias J., Theophanie. Die Geschichte einer alttestamentlichen Gattung (Wissenschaftliche Monographien zum Alten und Neuen Testamenten, 10), Neukirchener Verlag, Neukirchen-Vluyn 1965.

Joüon P., T. Muraoka, A Grammar of Biblical Hebrew (Subsidia Biblica, 14/1-2), Editrice Pontificio Istituto Biblico, Roma 2003, t. 1-2.

Kuhn G., Zur Assumptio Mosis, „Zeitschrift für die alttestamentliche Wissenschaft" 43 (1925), s. 124-129. 
Lacocque A., The Book of Daniel, tt. D. Pellauer, John Knox Press, Atlanta 1979.

Laperrousaz E.-M., Testament de Moïse, w: La Bible: Ecrits Intertestamentaires, red. A. Dupont-Sommer, M. Philonenko, Gallimard, Paris 1987, s. 993-1016.

Lester G.B., Daniel Evokes Isaiah: Allusive Characterization of Foreign Rule in the Hebrew-Aramaic Book of Daniel (Library of Hebrew Bible. Old Testament Studies, 606), Bloomsbury, T \& T Clark, London - New York 2015.

Lewis C.T., C. Short, A Latin Dictionary Founded on Andrews' Edition of Freund's Latin Dictionary, Revised, Enlarged, and in Great Part Rewritten, Clarendon Press, Oxford 1958 (pierwsza edycja: Oxford 1879).

Licht J., Taxo, or the Apocalyptic Doctrine of Vengeance, „Journal of Jewish Studies" 12 (1961), s. 95-103.

Maggiorotti D., La datazione del Testamento di Mosè, „Henoch” 15 (1993), s. 235-262.

McAlpine T.H., Sleep, Divine and Human in the Old Testament (Journal for the Study of the Old Testament. Supplement Series, 38), JSOT Press, Sheffield 1987.

Nickelsburg G.W.E., An Antiochan Date for the Testament of Moses, w: Studies on the Testament of Moses: Seminar Papers (Septuagint and Cognate Studies Series, 4), red. G.W.E. Nickelsburg, Society of Biblical Literature, Cambridge 1973, s. 33-37.

Nickelsburg G.W.E., Jewish Literature between the Bible and the Mishnah: A Historical and Literary Introduction, Fortress Press, Minneapolis 2005.

Nickelsburg G.W.E., Resurrection, Immortality, and Eternal Life in Intertestamental Judaism (Harvard Theological Studies, 26), Harvard University Press, Cambridge - Oxford University Press, London 1972.

Parchem M., „Co stanie się przy końcu dni” (Dn 2,28): wydarzenia czasów eschatologicznych $w$ świetle żydowskich pism apokaliptycznych okresu międzytestamentalnego, w: Czas Apokalipsy. Wizje dni ostatecznych w kulturze europejskiej od starożytności do wieku XVII, red. K. Zalewska-Lorkiewicz, Wydawnictwo Neriton, Warszawa 2013, s. 26-35.

Parchem M., Księga Daniela. Wstęp, przektad z oryginatu, komentarz (Nowy Komentarz Biblijny. Stary Testament, 26), Edycja św. Pawła, Częstochowa 2008.

Parchem M., Motyw zmartwychwstania w Księdze Daniela (Dn 12,2), w: Scripturae Lumen, Biblia i jej oddziaływanie: Zmartwychwstat prawdziwie, red. A. Paciorek, i in., Wydawnictwo Biblos, Tarnów 2010, t. 2, s. 65-77.

Parchem M., Ostateczne zwycięstwo Boga w walce między dobrem a złem w świetle pism z Qumran (Rozprawy i Studia Biblijne, 30), Oficyna Wydawnicza „Vocatio”, Warszawa 2008.

Parchem M., Rola Michała w przekazach o ,buncie w niebiosach” oraz „upadku aniołów”, w: Michał Archaniol, Zagadnienia teologiczne, red. H. Oleschko, S. Łącki, Wydawnictwo Michalineum, Marki 2012, t. 1, s. 123-164. 
Parchem M., Teofania w 1 Hen 1,3c-9 w kontekście tradycji biblijnej, w: Studia z biblistyki, red. R. Bartnicki, Wydawnictwo Uniwersytetu Kardynała Stefana Wyszyńskiego, Warszawa 2012, t. 8, s. 73-108.

Parchem M., Testament Mojzesza. Wprowadzenie, thumaczenie i noty, w: Pisma apokaliptyczne i testamenty (Apokryfy Starego Testamentu, 2), red. M. Parchem, The Enigma Press, Kraków - Mogilany 2010, s. 305-340.

Priest J., Testament of Moses (First Century A.D.). A New Translation and Introduction, w: The Old Testament Pseudepigrapha, Apocalyptic Literature and Testaments, red. J.H. Charlesworth, i in., Doubleday, New York 1983, t. 1, s. 919-934.

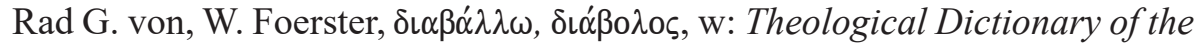
New Testament, red. G. Kittel, tł. G.W. Bromiley, William B. Eerdmans Publishing Company, Grand Rapids 1993, t. 2, s. 71-81.

Russell D.S., The Method and Message of Jewish Apocalyptic 200 BC-AD 100 (The Old Testament Library), The Westminster Press, Philadelphia 1964.

Schürer E., The History of the Jewish People in the Age of Jesus Christ (175 B.C. - A.D. 135). A New English Version Revised and Edited by G. Vermes, F. Millar, M. Black, T \& T Clark LTD, Edinburgh 1995, t. 2-3.

Stone M.E., Apocalyptic Literature, w: Jewish Writings of the Second Temple Period. Apocrypha, Pseudepigrapha, Qumran Sectarian Writings, Philo, Josephus (Compendia Rerum Iudaicarum ad Novum Testamentum, II/2), red. M.E. Stone, Van Gorcum, Assen - Fortress Press, Philadelphia 1984, s. 383-441.

Stuckenbruck L.T., 1 Enoch 91-108 (Commentaries on Early Jewish Literature), Walter de Gruyter, Berlin - New York 2007.

Trever J.C., The Book of Daniel and the Origin of the Qumran Community, „The Biblical Archaeologist” 48 (1985), s. 89-102.

Tromp J., The Assumption of Moses. A Critical Edition with Commentary (Studia in Veteris Testamenti Pseudepigrapha, 10), Brill, Leiden 1993.

Volz P., Die Eschatologie der jüdischen Gemeinde im neutestamentlichen Zeitalter, J.C.B. Mohr (Paul Siebeck), Tübingen 1934 (reprint: Georg Olms Verlagsbuchhandlung, Hildesheim 1966).

Witczyk H., Teofania w Psalmach, Polskie Towarzystwo Teologiczne, Kraków 1985.

Yarbro Collins A., Composition and Redaction of the Testament of Moses 10, „Harvard Theological Review” 69 (1976), s. 179-186.

Zeilinger F., Wiara $w$ zmartwychwstanie w Biblii (Myśl Teologiczna, 69), tł. G. Rawski, Wydawnictwo WAM, Kraków 2011.

Zerbe G., Pacifism and Passive Resistance in Apocalyptic Writings: A Critical Evaluation, w: The Pseudepigrapha and Early Biblical Interpretation (Journal for the Study of the Pseudepigrapha. Supplement Series, 14; Studies in Scripture in Early Judaism and Christianity, 2), red. J.H. Charlesworth, C.A. Evans, JSOT Press, Sheffield 1993, s. 65-95. 